\title{
BIBLIOGRAPHY AND ABBREVIATIONS
}

The three annotated bibliographies by Margolin (see below) provide an abundance of scholarship and criticism on The Praise of Folly for the years 1936-70. In the footnotes, apart from the abbreviations I have given here, I have adopted common abbreviations for Latin and Greek works (as used, for example, in The Oxford Classical Dictionary, Oxford, 1949; $A$ Latin Dictionary, ed. C.T. Lewis and C. Short, Oxford, I95I; and $A$ Greek-English Lexicon, ed. H. Liddell and R. Scott, Oxford, 1925). All unidentified translations are my own.

\section{EDITIONS, COMMENTARIES, TRANSLATIONS OF The Praise of Folly}

Bibliotheca Belgica: Bibliographic générale des Pays Bas, ed. F. van der Haeghen, Ghent, 1898-1923. Vol. 13, which is devoted entirely to Erasmus, appears in vol. 2, 271-1048, of the reissue, ed. Marie-Thérèse Lenger, 6 vols., Brussels, 1964-70.

Éloge de la Folic, tr. Pierre de Nolhac, comm. Maurice Rat, Paris, 1936. Latin with facing translation. Includes Erasmus' letter to Dorp. Some original material in the commentary.

Hudson. See The Praise of Folly, below. 
Moric encomium, id est Stulticiac laudatio . . . Jerome Froben and Nikolaus Bischoff, Basel, I532. The last edition revised by Erasmus. Contains both the text and the Lister commentary in their final form.

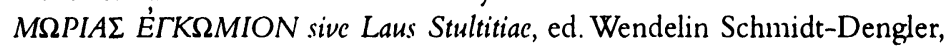
tr. Alfred Hartmann, Ausgewählte Schriften, Darmstadt, I975.

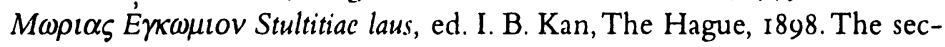
ond original commentary.

The Praise of Folic, tr. Sir Thomas Chaloner, ed. Clarence H. Miller, Early English Text Society No. 257, Oxford, 1965. The first English translation (I549).

The Praise of Folly, tr. and comm. Hoyt H. Hudson, Princeton, 194I. Contains some original material in the commentary and an analysis in terms of the classical oration.

Praise of Folly and Letter to Martin Dorp 1515, tr. Betty Radice, comm. A. H. T. Levi, Penguin Books, I97I.

Stultitac laus . . . a facsimile of the Froben ISIS edition with marginal drawings by Holbein, ed. H. A. Schmid, Basel, I93I. The ISIS edition was the first to contain Lister's commentary.

Stultitiac laus, vol. 4, cols. 40I-504, in Opcra omnia, ed. Jean Leclerc, Leiden 1703-06. Reprints the Lister commentary.

\section{CRITICISM, INTERPRETATION, AND RELATED WORKS}

Amsterdam ed. Opera omnia Desiderii Erasmi Rotcrodami, vol. I (parts I-5), vol. 4 (part I), Amsterdam, I969-.

Augustijn, Cornelis. Erasmus: His Life, Works, and Influence, tr. J. C. Grayson, Toronto, I99I.

Bainton, Roland. Erasmus of Christendom, New York, 1969.

Burgess, Theodore C. Epidcictic Litcraturc, Chicago, I902.

CCSL. Corpus Christianorum: Scrics Latina, Turnhold, 1954-65.

Volumes numbered to $\mathrm{I} 76$, of which 49 have been published.

Chomarat, Jacques. "L' 'Éloge de la Folie' et Quintilien." Information littérairc, No. 2 (1972): 77-82.

Christian, Lynda G. "The Metamorphoses of Erasmus' "Folly'." Journal of the History of Idcas, 32 (I97I): 289-94.

CSEL. Corpus scriptorum ccclesiasticorum Latinorum, 83 vols., Vienna, 18661971.

Curtius, Ernst. European Litcraturc and the Latin Middle Ages, New York, I953. 
$C W$. See More, below.

Dorey, Thomas A., ed. Erasmus, Albuquerque, 1970.

Ep. obscur. vir. Epistolac obscurorum virorum, Latin text with an English rendering . . . by F. G. Stokes, London, I925.

Erasmus, Adag. "Adagia," Opera (see Op., below), Vol. 2.

- See Amsterdam ed., above.

Coll. The Colloquies of Erasmus, tr. Craig R. Thompson, Chicago, 1965 .

Copia. On Copia of Words and Ideas, tr. and ed. D. B. King and H. D. Rix, Milwaukee, Wisc., 1963.

- Corresp. The Correspondence of Erasmus, tr. and ed. R. A. B. Mynors et al., vols. 1-4, Toronto, 1974-.

- Educ. Chr. Pr. The Education of a Christian Prince, tr. Lester Born, New York, I968.

- Enchiridion, Enchiridion militis Christiani, tr. Raymond Himelick, Bloomington, Ind., 1963.

- Ep. Opus epistolarum Des. Erasmi Roterodami, ed. P. S. Allen et al., 12 vols., Oxford, 1906-58.

- Erasmus on his Time: a Shortened Version of the Adages of Erasmus, tr. Margaret Mann Phillips, Cambridge, 1967.

- The Essential Erasmus, ed. John P. Dolin, New York, I964.

_ Julius Exclusus, tr. Paul Pascal, ed. J. K. Sowards, Bloomington, Ind., 1968.

Op. Opcra omnia, ed. Jean Leclerc, Leiden, 1703-06.

Selected Letters. Erasmus and his Agc: Selected Letters of Desidirius Erasmus, tr. Marcus Haworth, S. J., ed. Hans J. Hillerbrand, New York, 1970.

Selected Writings. Christian Humanism and the Reformation: Selected Writings of Erasmus with the Life of Erasmus by Beatus Rhenanus, ed. John C. Olin, New York, 1965.

Gavin, J.Austin. "The Commentary of Gerardus Listrius on Erasmus' Praise of Folly: a Critical Edition and Translation with Introduction and Commentary." Unpublished doctoral dissertation, St. Louis University, 1973.

Gavin J. Austin, and Walsh, Thomas M. "The Praise of Folly in Context: the Commentary of Girardus Listrius." Renaissance Quarterly, 24 (I97I): 193-209.

Gordon, Walter M. Humanist Play and Belief: The Seriocomic Art of Desiderius Erasmus, Toronto, 1990.

Kaiser, Walter. Praiscrs of Folly, Cambridge, Mass., I963. 


\section{BIBLIOGRAPHY AND ABBREVIATIONS}

Kay, W. David "Erasmus' Learned Joking: the Ironic Use of Classical Wisdom in The Praise of Folly." Texas Studics in Litcrature and Language, 19 (1977): 247-67.

Könneker, Barbara. Wesen und Wandlung der Narrenidec im Zeitalter des Humanismus: Brant-Murner-Erasmus, Wiesbaden, 1960.

Kristeller, Paul O. "Erasmus from an Italian Perspective." Renaissance Quarterly, 23 (I970): I-I4.

Lefebvre, Joël. Les fols ct la folic, Paris, 1968.

Margolin, Jean-Claude. Douze années de bibliographic érasmicnne 1950-1961, Paris, 1963.

- Quatorze années de bibliographic érasmienne 1936-1949, Paris, 1969.

- Neuf annécs de bibliographic érasmicnne 1962-1970, Paris and Toronto, 1977.

McConica, James. Erasmus, Oxford, I99I.

Miller, Clarence H. "Some Medieval Elements and Structural Unity in Erasmus' The Praise of Folly." Renaissance Quarterly, 27 (1974): 499-SII.

More, Thomas. The Correspondence of Sir Thomas More, ed. E. Rogers, Princeton, 1947 .

- $C W$. The Yale Edition of the Complete Works of St. Thomas More. $C W$ 3: Translations of Lucian, ed. Craig Thompson, New Haven, 1974, $\mathrm{CW}_{4}$ : Utopia, ed. Edward Surtz, S. J. and J. H. Hextor, New Haven, I965. Selected Letters. St. Thomas More: Selected Letters, ed. E. Rogers, tr. Marcus Haworth, New Haven, I96r.

-Utopia, tr. Clarence H. Miller, New Haven, 2001.

Otto, August. Die Sprichwörter und sprichwörtlichen Redensarten der Römer, Leipzig, 1890.

Payne John. Erasmus: his Theology of the Sacraments, Richmond,Va., 1970.

Pease, Arthur S. "Things without Honor." Classical Philology, 21 (I926): 27-42.

PG. Patrologiae cursus completus, scries Gracca, ed. J. P. Migne, I6I vols., Paris, I857-66.

PL. Patrologiac cursus completus, scrics Latina, ed. J. P. Migne, 22 I vols., Paris, I844-90

Rebhorn, Wayne A. "The Metamorphoses of Moria: Structure and Meaning in The Praise of Folly." Publications of the Modern Language Association, 89 (1974): 463-76.

Rechtien, John. "A I 520 French Translation of the Moriac Encomium." Renaissance Quarterly, 27 (1970): 23-35.

Rothschild, Herbert B. "Blind and Purblind: A Reading of The Praise of Folly." Neuphilologus, 54 (1970): 223-34. 
Schäfer, Eckart. "Erasmus und Horaz." Antike und Abenland, 16 (1970) $54-67$.

Schmidt-Dengler, Wendelin. Introduction to Laus Stultitia (LatinGerman), Ausgewählte Schriften von Erasmus, 8 vols., 2 (Darmstadt, I975), ix-xxix.

Sunith, Preserved. Erasmus: a Study of his Life, Ideals, and Place in History, New York, 1923, rpt. 1962.

Sowards, J. Kelley. Desiderius Erasmus, Boston, I975.

Stenger, Genevieve. "The Praise of Folly and its Parerga." Medicvalia et Humanistica, N.S., No. 2 (197I): 97-117.

Swain, Barbara. Fools and Folly during the Middle Ages and the Renaissance, New York, 1932.

Sylvester, Richard S. "The Problem of Unity in The Praise of Folly." English Litcrary Renaissance, 6 (1970): 125-39.

Thompson, Craig R. "Better Teachers than Scotus or Aquinas" in Medicval and Renaissance Studics (Southeastern Institute of Medieval and Renaissance Studies, No. 2, I966), ed. John L. Lievsay, Durham, N. C., 1968, pp. II4-45.

Thompson, Sister Geraldine. "Erasmus and the Tradition of Paradox." Studies in Philology, 61 (1964): 41-63.

Under Pretext of Praise: Satiric Mode in Erasmus' Fiction, Toronto, 1973.

Tilley, Morris P. A Dictionary of the Proverbs in England in the Sixteenth and Seventeenth Centuries, Ann Arbor, 1950.

Tracey, James. Erasmus: the Growth of a Mind, Geneva, 1972.

Trillitzsch, Winfried. "Erasmus und Seneca." Philologus, 109 (1965): 270-93

Walther, Hans. Proverbia sententiacque Latinitatis medii acvi, Göttingen, 1963-69.

Watson, Donald G. "Erasmus' Praise of Folly and the Spirit of Carnival." Renaissance Quarterly, 32 (1979): 333-353.

Welsford, Enid. The Fool: his Social and Literary History, London, 1935.

Willeford, W. The Fool and his Scepter, Chicago, 1969.

Williams, Kathleen, ed. Twentieth-Century Interpretations of the Praise of Folly, Englewood Cliffs, N. J., 1969. 
